\title{
Evaluation of nematicidal potential of neem sawdust against Meloidogyne arenaria on eggplant
}

\author{
Asgar Ali $^{\star}$ \& Kamal Singh \\ Department of Botany, D.S. College, Aligarh-202 001, India, affiliated to Dr. Bhim Rao Ambedkar University, Agra-282 004, India \\ *Email: aliasgar5383@gmail.com
}

\section{OPEN ACCESS}

\section{ARTICLE HISTORY}

Received: 15 September 2021

Accepted: 28 December 2021

Available online

Version 1.0: 13 February 2022

\section{Check for updates}

\section{Additional information}

Peer review: Publisher thanks Sectional Editor and the other anonymous reviewers for their contribution to the peer review of this work.

Reprints \& permissions information is available at https://horizonepublishing.com/ journals/index.php/PST/open_access_policy

Publisher's Note: Horizon e-Publishing Group remains neutral with regard to jurisdictional claims in published maps and institutional affiliations.

Indexing: Plant Science Today, published by Horizon e-Publishing Group, is covered by Scopus, Web of Science, BIOSIS Previews, Clarivate Analytics, etc. See https:// horizonepublishing.com/journals/index.php/ PST/indexing_abstracting

Copyright: $\odot$ The Author(s). This is an openaccess article distributed under the terms of the Creative Commons Attribution License, which permits unrestricted use, distribution and reproduction in any medium, provided the original author and source are credited (https://creativecommons.org/licenses/ by/4.0/)

\section{CITE THIS ARTICLE}

Ali A, Singh K. Evaluation of nematicidal potential of neem sawdust against Meloidogyne arenaria on eggplant. Plant Science Today 2022; 8(sp1): 33-43. https://doi.org/10.14719/ pst. 1485

\begin{abstract}
The present study was conducted to evaluate the impact of amending soil with decomposed neem (Azadirachta indica) sawdust at different concentrations (0-100\%) against different inoculum levels (0-4000) of root-knot nematode (Meloidogyne arenaria) infecting the eggplants. Various physicochemical properties of the soil increase as the concentration of decomposed neem sawdust (NSD) in the field soil increases. Nevertheless, the nitrogen content of the soil decreased with a progressive fluctuation in NSD. Lower levels (10-30\%) of NSD, with and without different inoculum levels, improve the plant growth and photosynthetic pigment content significantly compared to controls (plants with uninoculated soil) as well as inoculated plants. The maximum improvement in the growth and photosynthetic pigments was recorded at 30\% NSD soil amendment and this was continuously effective against all the nematode inoculum levels. At higher levels of NSD (40-100\%), all the studied growth and photosynthetic parameters were decreased gradually to control and a similar reductional trend was also observed on nematode inoculated eggplants. On root-knot nematode reproduction, NSD at all levels progressively suppressed the number of egg masses but enhanced the number of galls only up to $30 \%$. Galling was, however, totally absent in $70 \%$ and onward dust treatments of eggplants. Conclusively, NSD suppressed plant growth and photosynthetic pigments along with nematode buildup beyond $40 \%$ amendments. Thus, lower NSD levels (up to $30 \%$ amendments) will be recommended as growth and photosynthetic pigments supplement to eggplants, which also have nematicidal potential against egg masses of nematodes.
\end{abstract}

\section{Keywords}

Eggplant, Neem sawdust, Root-knot nematodes, Chlorophyll, Meloidogyne arenaria

\section{Introduction}

Root-knot nematodes (Meloidogyne spp.) are biotrophic polyphagous sedentary endoparasitic phytopathogens $(1,2)$. They almost exclusively feed on the roots of all vascular plants. They primarily cause major economic damage to a variety of crops, including solanaceous species $(3,4)$. M. arenaria, M. incognita, M. hapla and $M$. javanica are significant species with a diverse range of host plants $(5,6)$. These hidden phytopathogenic animals cause a loss of $\$ 157$ billion per year (7). Vegetables are high quality; low-cost sources of carbohydrates, proteins, vitamins and minerals with fibers, all of which have potential health benefits (8). Likewise, eggplant (Solanum melongena L.) is the most popular and commonly cultivated for its fruits 
that are eaten as vegetables all over the world. It is an important crop grows in the tropical and sub-tropical region of the world. It is also widely cultivated in Asia (9). According to FAO statistics (10), world production of $S$. melongena was estimated to be approximately 50 million tonnes in 2014; it is the fifth most commercially important cultivated solanaceous crop after potato, tomato, pepper and tobacco (11). In 2020, India used over 720 thousand hectares of agricultural land for vegetables; the volume of eggplant production in the last fiscal year was estimated to have been 12.68 million metric tonnes (12). This represented a slight decrease over the previous fiscal year. Eggplant is enriched in vitamins C, K, B6, niacin and thiamin, minerals and nutrients such as magnesium, phosphorus, zinc, folic acid, potassium, manganese and dietary fibers. It almost exclusively contains anthocyanins, has a low cholesterol level and protects us from so many dangerous diseases $(13,14)$.

Sawdust is a solid waste byproduct of the timber industry consisting of fine wood particles. Dumping of which has become an increasing economic and environmental issue due to its low bulk density and poor degradability. NSD is recognized today as a natural byproduct that has much to offer in solving global agricultural and environmental problems. Researchers worldwide are now focusing on the importance of NSD in the agricultural industry. The hundreds of its active ingredients are used to manage several pests, including root-knot nematodes (15-17). The natural properties of NSD do not have any toxic reactions at lower concentration levels, so it is helpful in the protection and management of crops from pests. As derived from the neem tree, it so acts as a powerful insect growth regulator and also helps in controlling several nematodes on so many crop plants. NSD has multipurpose use as an insecticide, pesticide, fertilizer and soil conditioner (18). NSD, as a fertilizer, has many advantages such as minimizes the requirement of crop nitrogen and hence reduces the cost of fertilizer, increases crop growth substantially and is very cost-effective, increases the efficiency of nitrogenous fertilizer at low concentration and better yield than other conventional fertilizers (19-21). Its nematotoxic properties can be attributed to the prevalence of triterpenoids and flavonoids including certain azadirachtin, nimbin, nimbidin, nimbidin acid, thionemone, kaempferol and quercetin, which suppress the root-knot nematode population $(22,23)$. However, some reports have also been suggested that NSD substantially decreased root-knot development on tomato and eggplant $(17,24)$. So many methods have already been applied to check the root-knot nematodes menace (25), amongst which organic amendments happen to be very reliable alternates. NSD is also having the potentiality against the root-knot nematode through soil amendments (17). It is not only beneficial at lower levels for nematodes like phytopathogens but also ameliorates the growth and leaf pigments of grown plants (26). NSD has been proved to be more effective than other plant-derived sawdust concerning nematode control (22). As apart from containing micro and macronutrients it also enriches the soil by way of im- proving the physico-chemical properties such as porosity, $\mathrm{pH}$, Cation exchange capacity (CEC) and water holding capacity (WHC) of the soil thus can be used as a soil improver (27). The main objectives of the present work are to apply the NSD in different concentrations to the field soil to evaluate its potential as a nematicide on eggplants.

\section{Materials and Methods}

\section{Host plant}

An eggplant was being used as a test plant (S. melongena L. var. Pusa Kranti). Its seeds were acquired from the National seed corporation (NSC), IARI, (PUSA) Campus New Delhi, India. They were indeed surface sterilized with 0.01 $\% \mathrm{HgCl}_{2}$ for 2 min before seeding. The sterilized seeds are sown in autoclaved soil stuffed clay pots in the green house, botanical garden of the Department of Botany, D.S. College, Aligarh, Uttar pradesh, India. Seedlings were transplanted into autoclaved soil in clay pots containing varying amounts of NSD mixed with soil when they were fifteen days old or at the three-leaved stage. M. arenaria, a root-knot nematode, has been handpicked as the test pathogen from the suburb of Aligarh, Uttar Pradesh, India after surveying the infested areas.

\section{Analysis of physico-chemical properties of soil}

The physico-chemical properties of soil with or without decomposing sawdust have been investigated just before seedling transplantation. Before analyzing the proposed properties of eleven (11) samples, tiny particles from each sample were obtained by running them across a fine sieve. Porosity and water holding capacity (WHC) have been evaluated by using proper methods $(28,29)$. Its $\mathrm{pH}$ was measured with a pH meter (Thermo Orion Model 290) and was calibrated with buffer of known $\mathrm{pH}$ (4.0 7.0 and 9.2) by standard method (30). Electrical conductivity (1:5 soil/soil mixture: water extract) was measured (30) and the cation exchange capacity (CEC) was subsequently be estimated by using phenolphthalein titrating method (31). Carbonates and bicarbonates content were also detected through the titration method (32). Chloride and sulphate content were also detected (30). Nitrogen (N) and phosphorus $(P)$ concentrations were also determined $(33,34)$. The diethylene triamine penta acetic acid (DTPA) tool was used to determine zinc ( $\mathrm{Zn})$, copper (Cu), iron (Fe) and manganese $(\mathrm{Mn})$, although the ammonium acetate method was used to determine potassium $(\mathrm{K})$ and magnesium $(\mathrm{Mg})$ content through a mixed acid digestion procedure (35).

\section{Pure culture and inoculation of root-knot nematode}

On the basis of above ground symptoms (Fig. 1A) infected eggplants were selected and their roots excised which infested with root-knot nematode ( Fig. 1B) were the source of nematodes, obtained from a severely infested suburb area of Aligarh, Uttar Pradesh, India. A single egg mass was put in a petri dish (Fig. 1C.) and the same egg laying female from the galls (Fig. 1D. ) was excised and placed underneath a binocular microscope to study and know the morphological characteristics of the Meloidogyne species. 

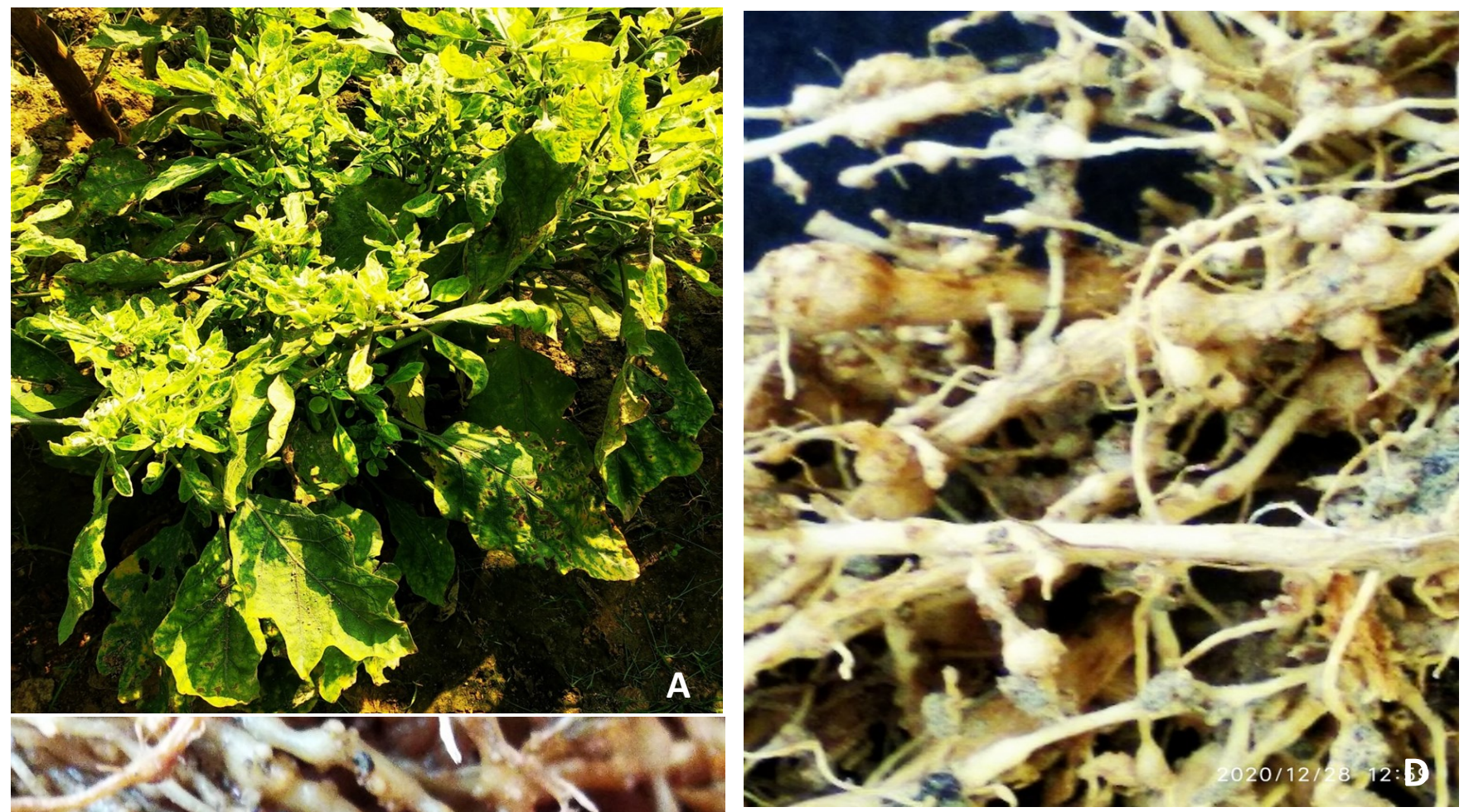

Fig. 1 (A). Above-ground symptoms (stunting, dwarfing and yellowing of leaves). (B). Egg masses of the root-knot nematode with galls on severely infected roots of eggplant. (C). Hand-picked egg masses collected in a petri dish. (D). Galls on roots of eggplant.

By observing certain morphological characteristics via anatomical section cutting through the posterior region of the nematode female, the confirmation with regard to Meloidogyne species was done. Through these sections, perennial pattern with special features has been observed for species confirmation. The confirmed species of Meloidogyne in the present experiment was M. arenaria (36). After M. arenaria (race 1) was verified, egg masses were extracted from the diseased root then put in a tiny coarse sieve $(1 \mathrm{~mm}$ pore size) wrapped with tissue paper preceding hatching in a 10 $\mathrm{cm}$ diameter petri dish with double distilled water. The second stage juveniles $\left(J_{2}\right)$ were injected into newly grown eggplant seedlings (S. melongena $\mathrm{L}$.) after hatching in a petri dish. After 45 days, the egg masses were sub-cultured in a similar fashion to acquire the desired numbers of egg masses. They were further inoculated into new eggplant roots to obtain sufficient inoculum. The roots were uprooted and rinsed, and cleaned with tap water before being sliced into $2 \mathrm{~cm}$ pieces for further testing. Sodium hypochlorite was used to remove the eggs. The eggs were coaxed to hatch into the distilled water petri dish. After $24 \mathrm{hrs}, \mathrm{M}$. arenaria second juveniles $\left(\mathrm{J}_{2}\right)$ were retrieved and employed for further studies. Three leaf stage seedlings were transplanted into clay pots containing various percentages of sterilized soil with decomposing NSD after two weeks into the depressions $(1.5 \mathrm{~cm} \times 3 \mathrm{~cm} \times 4 \mathrm{~cm})$ made in the soil around the base of eggplant seedlings according to the treatments. The suspension was taken in a pipette and inoculated to the soil and/ or NSD mixed sterilized clay pots. Similarly different amount of suspension was filled in the pipette and was inoculated the different clay pots, having a mixture of agricultural field soil and NSD to prepare different nematode inoculation treatments of $0,500,1000,1500,2000$, 2500, 3000, 3500 and 4000 inoculum levels as per designa- 
tion. All treatments were repeated 5 times and the clay pots were spread out on greenhouse benches $\left(30 \pm 2{ }^{\circ} \mathrm{C}\right)$ in a complete randomised block design (CRBD) at the botanical garden of D. S. College, Aligarh. After 99 days of growth, eggplants were harvested and measured for a range of characteristics.

\section{Collection of sawdust and experimental design}

NSD used in this experiment was obtained from a saw mill at Sikandra Rao, Hathras district, Uttar Pradesh, India. Collected NSD was allowed to decompose for three months in an elevated trench. After the decomposition, the sawdust was taken out and mixed with agricultural field soil. They were mixed in an appropriate proportion to achieve the varied concentrations (0\%, 10\%, 20\%, 30\%, 40\%, 50\%, 60\%, $70 \%, 80 \%, 90 \%$ and $100 \% \mathrm{w} / \mathrm{w})$. The mixture was allowed to dry in direct sunlight for at least a week. The size of clay pots used for filling the mixture belongs to $25 \mathrm{~cm}$ height $x$ $25 \mathrm{~cm}$ diameter size. An aperture was made in the middle of the basal part of each pot to maintain the proper circulation of water and air at the time of plant growth peak. The total amount of mixture filled in each pot was $3 \mathrm{~kg}$ in order to maintain the uniformity in the experimental work. Each treatment got 5 repeats, with or without the NSD and/or nematode. The treatments were as follows:

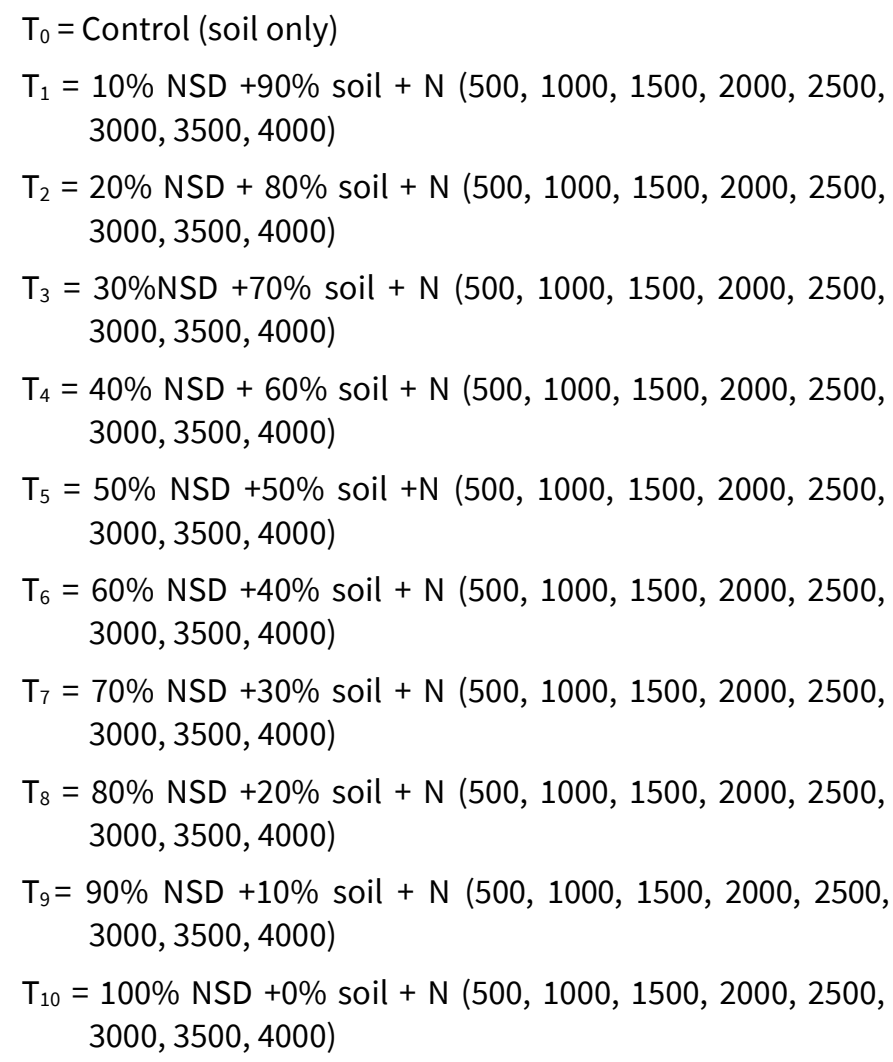

Where, T stands for treatments, NSD for neem sawdust and $\mathrm{N}$ for nematode.

All of the above treatments were inoculated separately by inoculum range starting from 500 to 4000 levels. Every such levelled treatment was further replicated 5 times i.e. with 5 replicates each.

\section{Growth Parameters evaluation}

On ninety-nine (99) days of growth after nematode inoculation, the eggplant crop was harvested, and the following considerations were taken into account for the experi- mental studies.

Determination of length, fresh and dry phytomass of root and shoot

The experiment was terminated after ninety-nine days of nematode inoculation. Just a few hrs. before the experiment ended, an excess amount of water was poured into the pots to moisten the soil as well as enable the eggplants to be carefully uprooted, avoiding significant root damage. Polybags holding uprooted plants were transferred to the department of botany at D.S. College Aligarh, Uttar Pradesh, India. A standard technique was used to measure the length of the plant shoot and root, as well as their fresh and dried phytomass. The shoot length was measured from the emerging point of the first root to the shoot apex, and even the root length was measured after cutting the stem above the emerging point of the first root. Fresh phytomass of every plant is taken in grams by electronic balance immediately after harvesting and for dry phytomass measurement, shoot and root were dried for $48 \mathrm{hrs}$. at $80{ }^{\circ} \mathrm{C}$ in a hot air oven. Then, it was measured by electronic balance (Wensar Weighing Scales Limited, India).

\section{Determination of Photosynthetic leaf pigment} (Chlorophyll)

One g $(1 \mathrm{~g})$ of fresh leaf from freshly harvested plants was mashed in $80 \%$ acetone for an estimate of leaf chlorophyll, and the mash was filtered through two Whatman Number 1 filter papers into a $100 \mathrm{ml}$ volumetric flask. The filtrate was amounted to $100 \mathrm{ml}$ after pouring an extra volume of $80 \%$ acetone. A spectrophotometer was used to measure the optical density at 645 and $663 \mathrm{~nm}$ to estimate chlorophyll a, b and total chlorophyll. The Mackinney method (1941) was used to determine the chlorophyll content of the supernatant (37). The formulae always used to calculate the chlorophyll content of eggplant leaves are listed below.

$\mathrm{Chl} \mathrm{a}=12.7$ (OD. 663) - $2.69(\mathrm{OD} .645) \times \mathrm{V} / 1000 \times \mathrm{W}(\mathrm{mg} / \mathrm{g})$

$\mathrm{Chl} \mathrm{b}=22.9$ (OD. 645) - $4.68(\mathrm{OD} .663) \times \mathrm{V} / 1000 \times \mathrm{W}(\mathrm{mg} / \mathrm{g})$

Total Chl = $20.2($ OD.645) $-8.02(\mathrm{OD} .663) \times \mathrm{V} / 1000 \times \mathrm{W}(\mathrm{mg} / \mathrm{g})$

Root-knot nematode reproductive parameters

Egg masses and galls enumeration

Following the experiment, the removed plant roots were gently rinsed with washing tap water, and the number of galls per root system was enumerated with the unaided eye. The roots of each collected eggplant were immersed for approximately $15 \mathrm{~min}$ in a $0.15 \mathrm{gL}^{-1}$ aqueous solution of Phloxine $B$, which would be routinely used to stain the gelatinous matrix of nematode egg masses, resulting in a deep red color. To follow this, egg masses were quantified per root system treated with varying nematode levels. The following scale was used to determine these parameters: $0=0,1=1-2,2=3-10,3=11-30,4=31-100$ and $5=$ more than 100 galls or egg masses per root system (38).

\section{Data analysis}

The evaluation of different physico-chemical properties of soil either with or without NSD, one factorial analysis was used. The data were subjected to an ANOVA table to determine the least significant difference (LSD) at $\mathrm{P}=0.05$ by the 
$\mathrm{R}$ analysis software. Two factors analysis (39) was used to ward NSD added treatments (Table 2-5). Increase in nemaevaluate data on eggplant growth, leaf pigment, and other tode density from zero (i.e. control) to the highest level (i.e. root-knot disease characteristics. The data are of two fac- 4000 inoculum level), all growth parameters, including pigtors in which sawdust was considered as factor one (F1) ments, were gradually suppressed. The eggplant grown in while different nematode inoculum levels were considered pure decomposed NSD had the lowest value for these paas factor two (F2). The LSD was thus calculated separately rameters. The highest suppression among them occurred at for these factors along with their interactive LSD at $\mathrm{P}=0.053000$ nematode inoculation levels, but this suppression was by using R software. somewhat obscured at 3500 and 4000 nematode inoculation levels compared to 3000 , though it was still greater than control. In each of these decomposed NSD-treated

\section{Results}

and untreated eggplants, root-knot nematode suppressed

The data demonstrate that with the increase in NSD levels, eggplant growth and leaf pigmentation substantially. Inthe $\mathrm{pH}$, cation exchange capacity (CEC), water holding ca- crease in the decomposed NSD concentration in the soil, pacity (WHC) and porosity of soil increased progressively the nematode suppressive effects diminished significantly.

Table 1. Analysis of different physico-chemical properties of soil and neem sawdust (NSD)-soil mixture

\begin{tabular}{|c|c|c|c|c|c|c|c|c|c|c|c|c|c|c|c|c|c|}
\hline \multirow{2}{*}{$\begin{array}{c}\text { NSD \% } \\
0\end{array}$} & \multirow{2}{*}{$\begin{array}{c}\text { Poro. } \\
49.0\end{array}$} & \multirow{2}{*}{$\begin{array}{c}\text { pH } \\
6.1\end{array}$} & \multirow{2}{*}{$\begin{array}{l}\text { WHC } \\
32.9\end{array}$} & \multirow{2}{*}{$\begin{array}{l}\text { CEC } \\
5.8\end{array}$} & \multirow{2}{*}{$\begin{array}{c}\text { Cond. } \\
3.7\end{array}$} & \multirow{2}{*}{$\begin{array}{l}\text { Carb } \\
0.40\end{array}$} & \multirow{2}{*}{$\begin{array}{c}\text { Bicarb } \\
0.67\end{array}$} & \multicolumn{2}{|c|}{ Sulphate chlorides } & \multirow{2}{*}{$\begin{array}{c}\mathbf{N} \\
0.14\end{array}$} & \multirow{2}{*}{$\begin{array}{c}\mathbf{P} \\
0.06\end{array}$} & \multirow{2}{*}{$\begin{array}{c}\mathbf{K} \\
0.22\end{array}$} & \multirow{2}{*}{$\begin{array}{c}\text { Mg } \\
0.06\end{array}$} & \multirow{2}{*}{$\begin{array}{c}\text { Mn } \\
2.10\end{array}$} & \multirow{2}{*}{$\begin{array}{c}\text { Zn } \\
1.12\end{array}$} & \multirow{2}{*}{$\begin{array}{c}\mathrm{Cu} \\
2.10\end{array}$} & \multirow{2}{*}{$\begin{array}{c}\mathbf{F e} \\
7.28\end{array}$} \\
\hline & & & & & & & & 4.52 & 0.30 & & & & & & & & \\
\hline 10 & 50.8 & 6.7 & 42.5 & 6.0 & 3.8 & 0.62 & 1.25 & 4.89 & 0.84 & 0.13 & 0.08 & 0.24 & 0.11 & 8.33 & 10.45 & 8.33 & 10.54 \\
\hline 20 & 53.9 & 5.8 & 45.8 & 6.1 & 4.1 & 0.93 & 1.77 & 5.09 & 1.06 & 0.12 & 0.14 & 0.27 & 0.14 & 9.31 & 21.70 & 9.31 & 131.90 \\
\hline 30 & 64.2 & 7.1 & 49.1 & 6.1 & 4.2 & 1.18 & 2.13 & 5.46 & 1.45 & 0.10 & 0.25 & 0.30 & 0.26 & 15.98 & 27.56 & 15.98 & 154.86 \\
\hline 40 & 66. & 7.4 & 55.7 & 6.2 & 4.3 & 1.20 & 2.16 & 5.71 & 1.50 & 0.09 & 0.27 & 0.36 & 0.28 & 16.40 & 31.60 & 16.40 & 164.50 \\
\hline 50 & 67.5 & 7.4 & 67.3 & 6.2 & 4.5 & 1.22 & 2.35 & 5.78 & 1.53 & 0.07 & 0.28 & 0.42 & 0.31 & 16.95 & 32.70 & 16.95 & 168.83 \\
\hline 60 & 68.1 & 7.5 & 77.9 & 6.3 & 4.7 & 1.22 & 2.40 & 6.27 & 1.58 & 0.05 & 0.30 & 0.47 & 0.33 & 17.20 & 33.90 & 17.20 & 171.70 \\
\hline 70 & 69.5 & 7.6 & 82.1 & 6.3 & 4.7 & 1.31 & 2.42 & 6.72 & 1.60 & 0.00 & 0.31 & 0.51 & 0.37 & 17.30 & 34.68 & 17.30 & 176.50 \\
\hline 80 & 70.9 & 7.8 & 84.2 & 6.4 & 4.8 & 1.33 & 2.49 & 6.80 & 1.64 & 0.00 & 0.37 & 0.67 & 0.40 & 17.59 & 35.70 & 17.59 & 178.90 \\
\hline 90 & 72.6 & 7.9 & 85.9 & 6.4 & 5.2 & 1.35 & 2.54 & 6.87 & 1.66 & 0.00 & 0.40 & 0.79 & 0.45 & 17.85 & 36.60 & 17.85 & 184.62 \\
\hline 100 & 83.5 & 7.9 & 87.6 & 6.6 & 5.2 & 1.38 & 2.69 & 6.90 & 1.74 & 0.00 & 0.46 & 0.96 & 0.50 & 18.50 & 37.49 & 18.50 & 185.70 \\
\hline $\begin{array}{c}\text { LSD at5\% } \\
(P \leq 0.05)\end{array}$ & 0.92 & 1.02 & 2.89 & 1.7 & 0.89 & 0.78 & 1.34 & 2.06 & 1.01 & 0.007 & 0.018 & $0 . .32$ & 0.020 & 20.04 & 1.71 & 0.987 & 8.89 \\
\hline
\end{tabular}

NSD = neem sawdust, Poro = porosity, $\mathrm{WHC}=$ water holding capacity, CEC = cation exchange capacity, Cond. = conductivity, Carb =carbonate, $\quad$ Bicarb = bicarbonate

(Table 1 ). The concentrations of sulphate, carbonate, bicar- Decomposed NSD, above a concentration of $30 \%$, was bonate, and chloride in all NSD amendments were also shown to be harmful to eggplant growth and photosynthetmeasured in different mixtures. Their enhancement was ic pigments even in presence of different nematode inocuconcentration-dependent that is their value were greater in higher amendment compared to lower ones. As far as the nitrogen contents are concerned they are suppressed gradually with increasing NSD levels. They were $0.14 \%$ in normally used agricultural field soil and reduced in all onwards amendments, up to the level of $60 \%$ NSD. Nitrogen contents were found nil in $70 \%$ and in all subsequent NSD additions. A steady increase in various metals (magnesium, manganese, copper, zinc and iron) was also seen on progressive increase in NSD levels in the soil. Metals were present in maximum proportion in pure NSD.

\section{Plant growth and photosynthetic pigment}

Plant growth (length, fresh and dry phytomass of shoot and root) and photosynthetic pigments (chlorophyll a, Chl b and total $\mathrm{Chl}$ ) were enhanced up to $30 \%$ decomposed NSD levels, which are shown in Tables 2-5. NSD, above the concentration of $30 \%$, was proved to be harmful to plant growth and photosynthetic pigments (Fig. 2A ). In 40\% NSD additions, the growth parameters along with leaf pigments were found at par with that of control that is NSD untreated plants. However, they were decreased abruptly in $40 \%$ on-
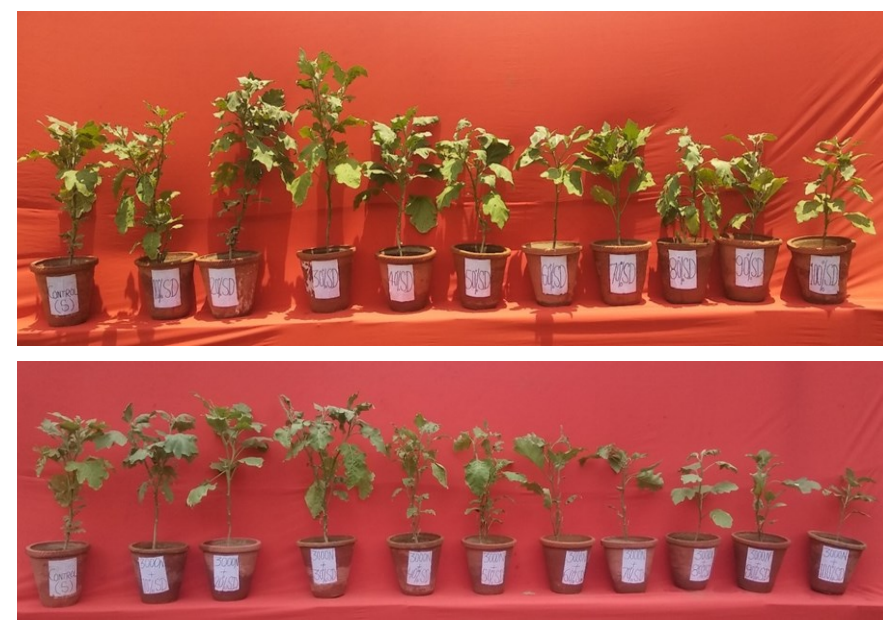

Fig. 2(A). Effect of different concentrations $\left(T_{1}, T_{2}, T_{3}, T_{4}, T_{5}, T_{6}, T_{7}, T_{8}, T_{9}, T_{10}\right)$ of NSD on eggplant growth. 2(B). Effect of different concentration of NSD and root-knot nematode with 3000 inoculum level on eggplant growth.

lum levels (Fig. 2B ). The eggplant grown in pure decomposed NSD had the lowest value of these parameters in all the nematode inoculum level treatments. 
Egg masses and Galls

decreased the number of egg masses which has been evi-

Different concentrations of decomposed NSD substantially dent from Table 6. Their number was decreased gradually

Table 2. Effect of neem sawdust and different inoculum levels of $M$. arenaria on length of shoot and root of eggplant

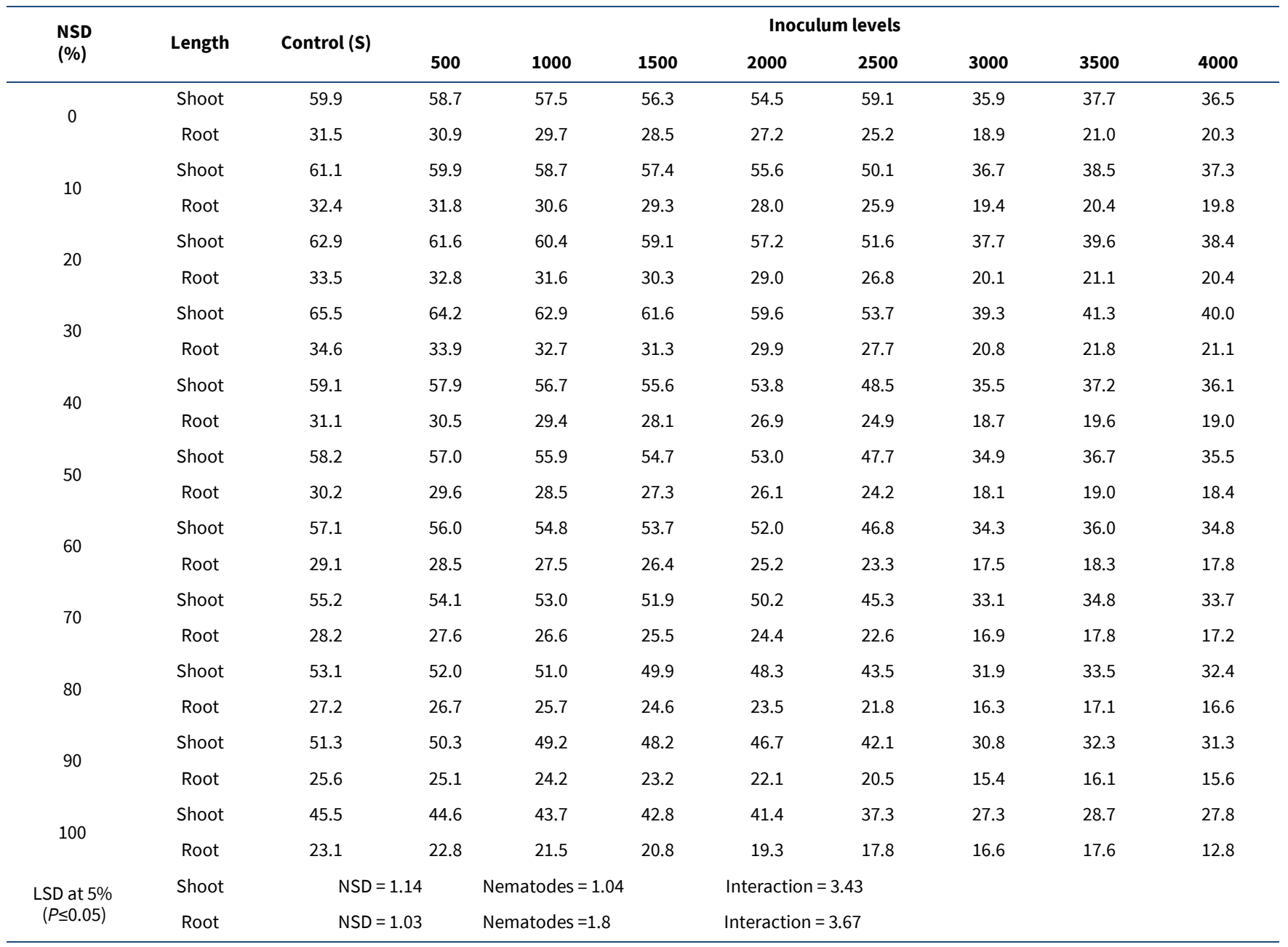

Table 3. Effect of neem sawdust and different inoculum levels of $M$. arenaria on fresh phytomass (g) of shoot and root of eggplant

\begin{tabular}{|c|c|c|c|c|c|c|c|c|c|c|}
\hline \multirow{2}{*}{$\begin{array}{l}\text { NSD } \\
(\%)\end{array}$} & \multirow{2}{*}{$\begin{array}{c}\text { Fresh } \\
\text { phytomass }\end{array}$} & \multirow{2}{*}{$\begin{array}{c}\text { Control } \\
\text { (S) }\end{array}$} & \multicolumn{8}{|c|}{ Inoculum levels } \\
\hline & & & 500 & 1000 & 1500 & 2000 & 2500 & 3000 & 3500 & 4000 \\
\hline \multirow{2}{*}{0} & Shoot & 162.9 & 161.4 & 159.8 & 158.2 & 156.8 & 155.6 & 154.7 & 155.3 & 154.1 \\
\hline & Root & 77.8 & 76.9 & 75.8 & 74.9 & 73.8 & 72.9 & 71.5 & 72.1 & 71.4 \\
\hline \multirow[t]{2}{*}{10} & & & & & & & & & & \\
\hline & Root & 79.2 & 78.1 & 77.0 & 75.9 & 74.8 & 72.5 & 69.7 & 71.8 & 70.5 \\
\hline \multirow{2}{*}{20} & Shoot & 165.7 & 164.2 & 162.6 & 160.9 & 159.2 & 157.2 & 153.3 & 155.8 & 154.1 \\
\hline & Root & 81.1 & 80.0 & 78.8 & 77.7 & 76.6 & 74.2 & 71.4 & 73.5 & 72.2 \\
\hline 30 & Shoot & 168.9 & 167.4 & 165.7 & 164.0 & 162.3 & 160.3 & 156.2 & 158.8 & 1157.1 \\
\hline \multirow{2}{*}{40} & Shoot & 162.2 & 115.60 & 110.20 & 106.80 & 101.90 & 96.70 & 93.05 & 94.00 & 95.10 \\
\hline & Root & 76.9 & 56.50 & 53.60 & 48.40 & 46.20 & 42.60 & 40.50 & 41.30 & 40.90 \\
\hline \multirow{2}{*}{50} & Shoot & 160.5 & 110.70 & 107.90 & 102.90 & 97.90 & 94.50 & 91.10 & 92.20 & 91.50 \\
\hline & Root & 75.4 & 51.80 & 48.70 & 46.01 & 43.70 & 40.00 & 36.80 & 37.90 & 37.40 \\
\hline \multirow{2}{*}{60} & Shoot & 155.8 & 105.20 & 103.90 & 97.70 & 95.80 & 91.60 & 86.90 & 87.50 & 87.10 \\
\hline & Root & 73.6 & 48.90 & 46.80 & 43.60 & 40.00 & 39.10 & 35.50 & 36.90 & 35.80 \\
\hline
\end{tabular}




\begin{tabular}{|c|c|c|c|c|c|c|c|c|c|c|}
\hline \multirow{2}{*}{70} & Shoot & 150.2 & 103.60 & 100.01 & 95.90 & 91.60 & 88.90 & 84.90 & 85.80 & 85.10 \\
\hline & Root & 71.5 & 47.10 & 44.20 & 41.60 & 39.20 & 38.10 & 35.40 & 36.00 & 35.70 \\
\hline \multirow{2}{*}{80} & Shoot & 142.8 & 101.00 & 96.20 & 93.40 & 89.80 & 84.60 & 81.50 & 82.90 & 82.20 \\
\hline & Root & 47.20 & 44.90 & 42.70 & 39.90 & 37.60 & 35.90 & 33.70 & 34.80 & 33.60 \\
\hline \multirow{2}{*}{90} & Shoot & 100.02 & 95.70 & 93.01 & 90.20 & 85.40 & 83.10 & 79.10 & 80.50 & 79.80 \\
\hline & Root & 46.40 & 42.40 & 40.10 & 36.90 & 34.90 & 33.00 & 31.30 & 32.60 & 31.90 \\
\hline \multirow{2}{*}{100} & Shoot & 98.70 & 93.60 & 89.50 & 85.80 & 80.10 & 77.80 & 75.00 & 76.20 & 75.80 \\
\hline & Root & 45.70 & 40.90 & 37.80 & 35.10 & 32.90 & 30.80 & 29.50 & 30.80 & 29.70 \\
\hline \multirow{2}{*}{$\begin{array}{c}\text { LSD at } 5 \% \\
(P \leq 0.05)\end{array}$} & Shoot & \multicolumn{2}{|c|}{$\mathrm{NSD}=1.14$} & \multicolumn{2}{|c|}{ Nematodes $=1.04$} & \multicolumn{2}{|c|}{ Interaction $=3.43$} & & & \\
\hline & Root & \multicolumn{2}{|c|}{$N S D=3.45$} & \multicolumn{2}{|c|}{ Nematodes $=3.01$} & \multicolumn{2}{|c|}{ Interaction $=7.67$} & & & \\
\hline
\end{tabular}

Table 4. Effect of neem sawdust and different inoculum levels of $M$. arenaria on dry phytomass (g) of shoot and root of eggplant

\begin{tabular}{|c|c|c|c|c|c|c|c|c|c|c|}
\hline \multirow{2}{*}{$\begin{array}{r}\text { NSD } \\
(\%)\end{array}$} & \multirow{2}{*}{$\begin{array}{c}\text { Dry } \\
\text { phytomass }\end{array}$} & \multirow{2}{*}{$\begin{array}{l}\text { Control } \\
\text { (S) }\end{array}$} & \multicolumn{8}{|c|}{ Inoculum levels } \\
\hline & & & 500 & 1000 & 1500 & 2000 & 2500 & 3000 & 3500 & 4000 \\
\hline 0 & Shoot & 85.20 & 81.40 & 81.00 & 80.20 & 77.10 & 75.80 & 73.50 & 74.00 & 73.80 \\
\hline \multirow{2}{*}{10} & Shoot & 90.10 & 87.30 & 86.50 & 84.30 & 81.50 & 79.90 & 78.80 & 79.20 & 78.90 \\
\hline & Root & 45.90 & 43.10 & 42.50 & 41.70 & 40.40 & 39.80 & 38.20 & 38.90 & 38.40 \\
\hline 20 & Root & 46.10 & 45.20 & 44.40 & 43.00 & 42.06 & 41.70 & 40.90 & 41.50 & 41.30 \\
\hline \multirow{2}{*}{30} & Shoot & 105.40 & 100.10 & 98.60 & 95.40 & 94.30 & 91.60 & 90.50 & 90.80 & 90.65 \\
\hline & Root & 52.60 & 48.70 & 47.20 & 45.10 & 44.00 & 42.80 & 41.70 & 42.40 & 38.90 \\
\hline \multirow{2}{*}{40} & Shoot & 81.90 & 80.02 & 78.50 & 76.70 & 73.80 & 71.60 & 70.01 & 71.30 & 68.80 \\
\hline & Root & 42.10 & 40.06 & 39.01 & 38.20 & 37.60 & 35.10 & 34.02 & 34.40 & 33.10 \\
\hline \multirow{2}{*}{50} & Shoot & 78.70 & 76.60 & 75.10 & 73.60 & 71.70 & 68.40 & 65.10 & 66.02 & 65.50 \\
\hline & Root & 38.30 & 38.00 & 37.60 & 35.20 & 33.90 & 32.80 & 30.50 & 31.30 & 30.70 \\
\hline \multirow{2}{*}{60} & Shoot & 75.50 & 71.90 & 70.80 & 68.10 & 65.80 & 65.10 & 60.60 & 61.00 & 60.80 \\
\hline & Root & 36.10 & 35.20 & 34.50 & 32.60 & 31.00 & 30.50 & 30.00 & 30.70 & 30.00 \\
\hline \multirow{2}{*}{70} & Shoot & 72.90 & 70.30 & 69.40 & 66.90 & 65.02 & 64.20 & 55.50 & 56.40 & 55.80 \\
\hline & Root & 34.80 & 33.60 & 31.50 & 30.50 & 29.40 & 28.60 & 26.80 & 27.10 & 27.00 \\
\hline \multirow{2}{*}{80} & Shoot & 68.70 & 67.50 & 66.20 & 64.00 & 62.50 & 61.30 & 51.70 & 52.40 & 51.10 \\
\hline & Root & 32.90 & 31.30 & 30.00 & 29.10 & 28.00 & 27.50 & 27.10 & 28.00 & 27.30 \\
\hline \multirow{2}{*}{90} & Shoot & 57.00 & 56.10 & 54.90 & 53.70 & 51.00 & 49.01 & 47.60 & 48.20 & 47.70 \\
\hline & Root & 25.90 & 23.20 & 22.60 & 22.10 & 21.20 & 20.10 & 19.90 & 20.60 & 20.10 \\
\hline \multirow{2}{*}{100} & Shoot & 50.90 & 48.80 & 47.50 & 46.40 & 44.10 & 41.70 & 40.00 & 41.00 & 41.10 \\
\hline & Root & 23.80 & 22.00 & 21.30 & 20.00 & 19.50 & 19.00 & 18.50 & 19.30 & 18.70 \\
\hline $\begin{array}{c}\text { LSD at } 5 \% \\
(P \leq 0.05)\end{array}$ & Shoot & \multicolumn{2}{|c|}{$N S D=4.14$} & \multicolumn{2}{|c|}{ Nematodes $=3.04$} & \multicolumn{2}{|c|}{ Interaction = 3.5} & & & \\
\hline
\end{tabular}

Table 5. Effect of neem sawdust and different inoculum levels of $M$. arenaria on chlorophyll content ( $\mathrm{mg} / \mathrm{g}$ fresh leaf) in leaves of eggplant

\begin{tabular}{|c|c|c|c|c|c|c|c|c|c|c|}
\hline \multirow{2}{*}{$\begin{array}{l}\text { NSD } \\
(\%)\end{array}$} & \multirow{2}{*}{ Chl } & \multirow{2}{*}{$\begin{array}{c}\text { Control } \\
\text { (S) }\end{array}$} & \multicolumn{8}{|c|}{ Inoculum levels } \\
\hline & & & 500 & 1000 & 1500 & 2000 & 2500 & 3000 & 3500 & 4000 \\
\hline \multirow{4}{*}{0} & Chl. a & 2.50 & 2.47 & 2.44 & 2.39 & 2.33 & 2.20 & 2.10 & 2.15 & 2.12 \\
\hline & Chl. b & 1.70 & 1.68 & 1.63 & 1.61 & 1.56 & 1.47 & 1.36 & 1.39 & 1.38 \\
\hline & Total & 4.20 & 4.15 & 4.07 & 4.00 & 3.89 & 3.67 & 3.46 & 3.54 & 3.50 \\
\hline & Chl. a & 2.52 & 2.50 & 2.46 & 2.41 & 2.35 & 2.22 & 2.14 & 2.18 & 2.16 \\
\hline \multirow[t]{2}{*}{10} & Chl. b & 1.72 & 1.69 & 1.65 & 1.62 & 1.59 & 1.50 & 1.40 & 1.43 & 1.41 \\
\hline & Total & 4.24 & 4.19 & 4.11 & 4.03 & 3.94 & 3.72 & 3.54 & 3.61 & 3.57 \\
\hline
\end{tabular}




\begin{tabular}{|c|c|c|c|c|c|c|c|c|c|c|}
\hline & Chl. a & 2.56 & 2.53 & 2.51 & 2.45 & 2.37 & 2.25 & 2.19 & 2.23 & 2.21 \\
\hline \multirow[t]{3}{*}{20} & Chl. b & 1.76 & 1.72 & 1.70 & 1.66 & 1.63 & 1.54 & 1.45 & 1.49 & 1.46 \\
\hline & Total & 4.32 & 4.25 & 4.21 & 4.11 & 4.03 & 3.79 & 3.64 & 3.72 & 3.67 \\
\hline & Chl. a & 2.62 & 2.59 & 2.56 & 2.52 & 2.46 & 2.33 & 2.28 & 2.31 & 2.29 \\
\hline \multirow[t]{3}{*}{30} & Chl. b & 1.83 & 1.79 & 1.76 & 1.72 & 1.68 & 1.62 & 1.53 & 1.58 & 1.55 \\
\hline & Total & 4.45 & 4.38 & 4.32 & 4.24 & 4.14 & 3.95 & 3.81 & 4.89 & 3.84 \\
\hline & Chl. a & 2.49 & 2.44 & 2.40 & 2.36 & 2.22 & 2.18 & 2.05 & 2.06 & 1.98 \\
\hline \multirow[t]{3}{*}{40} & Chl. b & 1.68 & 1.65 & 1.61 & 1.48 & 1.41 & 1.27 & 1.24 & 1.26 & 1.19 \\
\hline & Total & 4.17 & 4.09 & 4.02 & 3.84 & 3.63 & 3.46 & 3.30 & 3.32 & 3.17 \\
\hline & Chl. a & 2.46 & 2.40 & 2.37 & 2.28 & 2.18 & 2.08 & 2.01 & 2.18 & 1.88 \\
\hline \multirow[t]{3}{*}{50} & Chl. b & 1.65 & 1.62 & 1.55 & 1.36 & 1.34 & 1.19 & 1.12 & 1.14 & 1.15 \\
\hline & Total & 4.11 & 4.02 & 3.92 & 3.64 & 3.53 & 3.27 & 3.13 & 3.33 & 3.04 \\
\hline & Chl. a & 2.41 & 2.38 & 2.30 & 2.24 & 2.16 & 2.06 & 1.85 & 1.95 & 1.78 \\
\hline \multirow[t]{3}{*}{60} & Chl. b & 1.61 & 1.57 & 1.49 & 1.29 & 1.20 & 1.12 & 1.06 & 1.11 & 1.10 \\
\hline & Total & 4.02 & 3.95 & 3.79 & 3.53 & 3.37 & 3.19 & 2.92 & 2.90 & 2.88 \\
\hline & Chl. a & 2.34 & 2.31 & 2.21 & 2.16 & 2.10 & 2.05 & 1.75 & 1.72 & 1.69 \\
\hline \multirow[t]{3}{*}{70} & Chl. b & 1.53 & 1.50 & 1.39 & 1.22 & 1.12 & 1.02 & 1.04 & 1.10 & 1.10 \\
\hline & Total & 3.87 & 3.81 & 3.60 & 3.38 & 3.22 & 3.07 & 2.79 & 2.82 & 2.80 \\
\hline & Chl. a & 2.25 & 2.21 & 2.13 & 2.10 & 2.00 & 1.78 & 1.60 & 1.69 & 1.61 \\
\hline \multirow[t]{3}{*}{80} & Chl. b & 1.43 & 1.40 & 1.28 & 1.17 & 1.08 & 0.95 & 0.98 & 0.91 & 0.89 \\
\hline & Total & 3.68 & 3.61 & 3.41 & 3.28 & 3.09 & 2.74 & 2.58 & 2.60 & 2.51 \\
\hline & Chl. a & 2.15 & 2.13 & 2.02 & 2.05 & 1.90 & 1.69 & 1.51 & 1.62 & 1.58 \\
\hline \multirow[t]{3}{*}{90} & Chl. b & 1.33 & 1.30 & 1.19 & 1.10 & 0.98 & 0.85 & 0.88 & 0.90 & 0.89 \\
\hline & Total & 3.48 & 3.43 & 3.21 & 3.15 & 2.88 & 2.54 & 2.49 & 2.52 & 2.47 \\
\hline & Chl. a & 2.02 & 1.99 & 1.88 & 1.90 & 1.89 & 1.60 & 1.47 & 1.60 & 1.57 \\
\hline \multirow[t]{2}{*}{100} & Chl. b & 1.20 & 1.18 & 0.90 & 0.98 & 0.87 & 0.75 & 0.67 & 0.69 & 0.68 \\
\hline & Total & 3.22 & 3.17 & 2.78 & 2.88 & 2.76 & 2.35 & 2.25 & 2.30 & 2.26 \\
\hline
\end{tabular}

Table 6. Effect of neem sawdust and different inoculum levels of $M$. arenaria on number of egg masses and galls on roots of eggplant

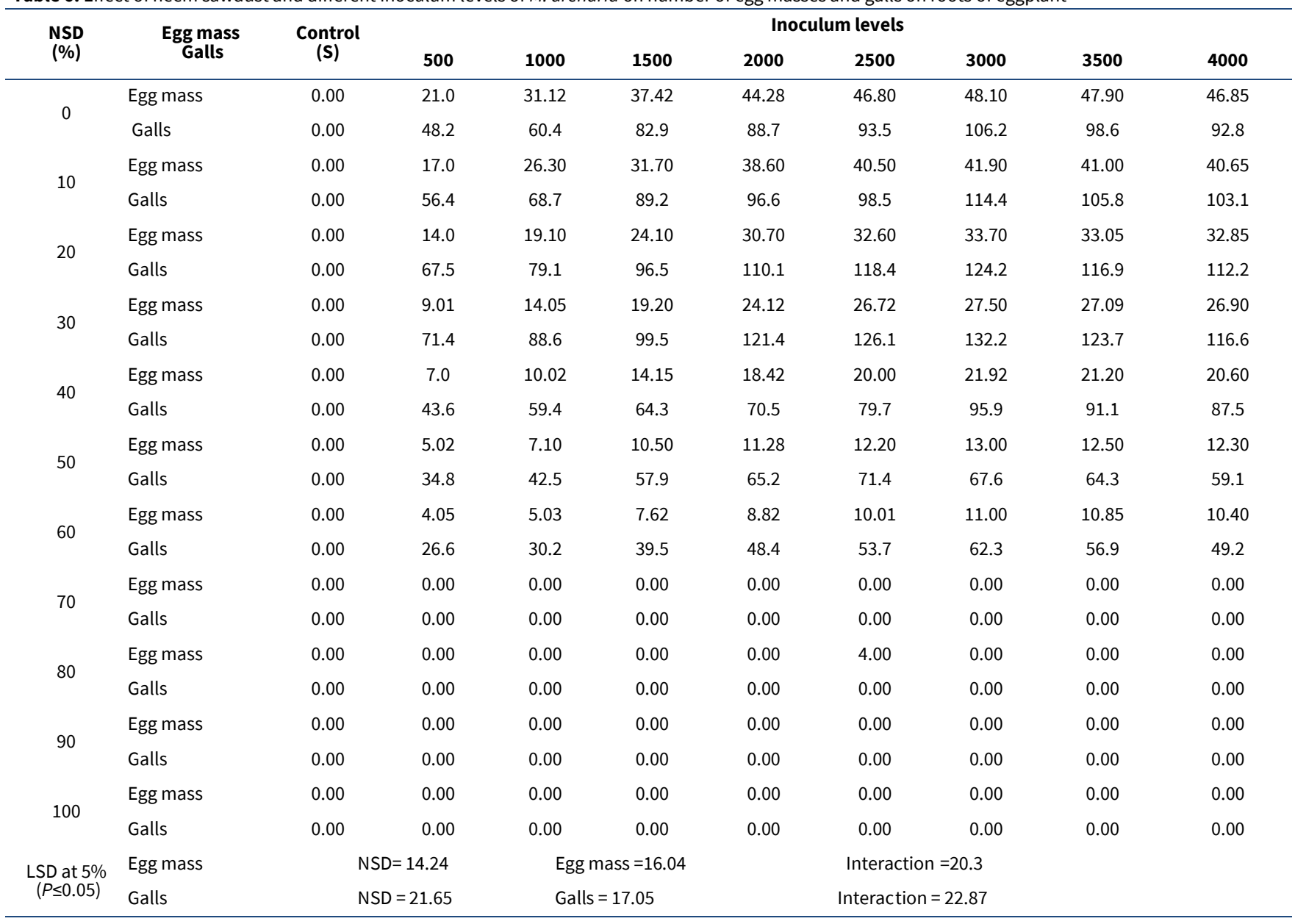


as there was an increase in NSD addition to soil. Number of egg masses was found minimum in 60\% NSD added soil treatments and would become totally nil in further dust amendments. The number of egg masses was also increased in all nematode inoculated treatments, although they were the maximum at 3000 nematode inoculum levels.

Their number was reduced somewhat in the rest of the two highest nematode levels but still significantly greater to control. As far as galls are concerned, their number increased up to $30 \%$ NSD amendments but decreased progressively up to $60 \%$ and then become zero in onward amendments. Galling was also increasing gradually with the inoculum increase and was the maximum at 3000 inoculum levels. Galls as well as egg masses were reduced slightly in 3500 and 4000 the inoculum levels but were still significantly greater than their respective controls (Table 6).

\section{Discussion}

NSD has progressively enhanced plant growth and photosynthetic pigments up to $30 \%$ amendments. There are some studies available with regard to favorable impacts of NSD on growth projections $(40,41)$. The improvement of soil physico-chemical characteristics with NSD amendments is consistent with previous research (19). The soil characteristics have been optimized most correctly at $30 \%$ NSD additions, as evidenced by the maximization of eggplant growth and pigments in these treatments. NSD had a detrimental impact on eggplant growth and pigments over $30 \%$ amendments. At a greater level, the accumulation of macro and micronutrients beyond the threshold limit for growing plants might be advocated as an argument for such growth antagonism. Nitrogen being an essential and integral component of chlorophyll $(42,43)$, its immobilization in greater NSD amendments may be regarded as a healthy reason for reductions in pigmentation and such negative impacts could also be seen on the growth parameters. Nematode infection causes the formation of galls by the process of hypertrophy and hyperplasia from which the nematode continues to suck the food by using their mouth parts. So the food and the nutrients flow to nematodes rather than available to plants $(1,44,45)$. Despite the galling formation, they also destroy the xylary elements. So the water availability was also hampered $(46,47)$. Such causes individually or mutually may be responsible for plantgrown retardation.

Up to 3000 nematode inoculum levels plant growth and leaf pigments reduced gradually due to referred as above reasons of changed anatomy of infected plants. These parameters were however, reduced along with all nematode inoculum levels, although their reductions were observed comparatively less at 3500 and 4000 inoculum levels compared to 3000 levels. However, at 3500 and 4000 inoculum levels, the plant growth and leaf pigments were slightly improved compared to 3000 inoculum level, however, the reductions were at large with that of control. Such insignificant growth enhancement can be connected to a reason of a kind of intra-specific competition among the nematodes for food and space, which might have subse- quently been reflected behind such slight improvised growth and pigments.

As shown in the results egg masses production was suppressed gradually up to $60 \%$ sawdust amendments, they were absent in onward NSD treatments. The reason advocated behind such reductions might be the accumulation of extraneous macro and micronutrients and phenolic compounds (48). Apart from this, their (egg masses) physical contact with the surrounding NSD stressed environment may also be connected to their reduced number (49). Another factor of their reduction can also be attributed for being the development and colonization of nematodes natural enemies (50). The number of egg masses was however increased as the inoculum level increased. This may be due to their second stage juveniles $\left(\mathrm{J}_{2}\right)$ greater ingression to the host root who might have subsequently been transformed into a greater number of females and thus a subsequently greater number of egg masses $(51,52)$.

According to our results, galls production was also gradually increased up to $30 \%$ amendments but decreased gradually in onward NSD amendments and completely absent from $70 \%$ to $100 \%$. On the other hand, they increased up to 3000 inoculum levels by adding the nematode numbers but these are found to be slightly decreased numbers above 3000 inoculum levels. An increase of galls up to $30 \%$ can be correlated with the favorable impacts of some improvised physical properties as $\mathrm{pH}$, porosity, WHC and CEC $(19,53)$. The galls were however totally absent from $70 \%$ onward NSD treatments, which may be because of adverse ambient stressed environment. The inhibition of nematodes by NSD can be associated with the presence of phenolic compounds in the sawdust $(53,54)$. At all nematode inoculum levels, there was a significant increase in the number of galls. The highest numbers of galls were established at a level of $3000 \mathrm{~J}_{2}$, followed by 2500 , and the lowest being with $500 \mathrm{~J}_{2}$ inoculated plant roots. So the peak of the galling was found in $3000 \mathrm{~J} 2$ inoculated treatments and it was moderately reduced in 3500 and 4000 inoculum used treatments. Such disturbance can result in the competition made for food and nutrients among the developing nematodes inside the root. The incapacity of $J_{2}$ to create new infection sites in the host roots for future generations might have facilitated for such decrease (55). Another factor contributing to their decline was the growth and colonization of nematode natural predators in increasing sawdust levels $(24,56)$. Nematophagous fungi colonized and reproduced more abundantly in sawdust supplemented soil treatments $(40,41)$ which could act as a bio-control agent to check the nematode blossoming.

\section{Conclusion}

So the way in the preceding discussion, we may assume that NSD might have been hazardous to the overall rootknot nematode disease of eggplant crop. As evident from reduced egg masses and galling conversely, NSD enhanced the growth rate by up to $30 \%$ production. NSD has been proved very hazardous to the root-knot nematodes as their number decreased to nil in its higher additions but such 
additions also contributed towards the lower eggplant 9. growth. Thus potentiality of NSD against root-knot nematode is being feasible if used as a lower addendum because such levels also improvised the growth

\section{Acknowledgements}

The author would like to express their appreciation to Dr. Abrar Ahmad Khan, Professor, Department of Botany, A.M.U., Aligarh, Uttar Pradesh, India, for his valuable technical support .

\section{Authors contributions}

$\mathrm{AA}$ and $\mathrm{KS}$ created the objectives and work plan, organized the experiment and authorized the necessary facilities. They also assisted in the experimental preparation. AA performed all tabulation and computations in the field and laboratory. AA reviewed the data and wrote the MS, as well as submitted it for the correction. KS offered valuable comments and assisted with the development of the MS in the present shape.

\section{Compliance with ethical standards}

Conflict of interest: The authors state that they do not have any conflict of interest/competing interest

Ethical issues: None.

\section{References}

1. Palomares-Rius JE, Escobar C, Cabrera J, Vovlas A, Castillo P. Anatomical alterations in plant tissues induced by plantparasitic nematodes. Front Plant Sci. 2017; 8:1987.https:// doi.org/10.3389/fpls. 01987

2. Abad P, Favery B, Rosso MN, Castagnone-Sereno P. Root-knot nematode parasitism and host response: Molecular basis of a sophisticated interaction. Mol Plant Pathol. 2003; 4:217-24. https://doi.org/10.1046/j.1364-3703.2003.00170.x

3. Vieira P and Gleason C. Plant-parasitic nematode effectors - insights into their diversity and new tools for their identification. Curr Opin Plant Biol. 2019; 50:37-43. https://doi.org/10.1016/ j.pbi.2019.02.007

4. Navyashree B, Dharmashekar C, Shivamallu C, Balasubramanian S, Prasad SK, Prasad KS, Latha KC. Plant induced resistance in Solanacearum lycopersicum species against root-knot nematodes. J App Biol Biotech. 2021;9(1):88-95. https:// doi.org/10.7324/JABB.2021.9112

5. Jones JT, Haegeman A, Danchin EGJ, Gaur HS, Helder J, Jones MGK. Top 10 plant-parasitic nematodes in molecular plant pathology. Mol Plant Pathol. 2013;14:946-61. https:// doi.org/10.1111/mpp.12057

6. Li X, Xing X, Xu S, Zhang M, Wang Y, Wu H. Genome-wide identification and functional prediction of tobacco IncRNAs responsive to root-knot nematode stress. PLoS One. 2018; 13 (11):e0204506.https://doi.org/10.1371/journal. pone.0204506

7. Bohlman $\mathrm{H}$, Sobczak M. The plant cell wall in the feeding sites of cyst nematodes. Front Plant Sci. 2014; 5: 89. https:// doi.org/10.3389/fpls.2014.00089

8. Otles S, Ozgoz S. Health effects of dietary fiber. Acta Sci Pol Technol Aliment. 2014;13(2):191-202.https://doi.org/10.17306/ J.AFS.2014.2.8
Weese T, Bohs L. Eggplant origins: out of Africa, into the Orient. Taxon. 2010; 59:49-56.https://doi.org/10.2307/27757050

10. FAO. FAOSTAT. Production Databases. Available online at: http:// www.faostat.fao.org (Accessed January 30, 2017)

11. Taher D, Solberg SO, Prohens J, Chou Y, Rakha M, Wu T. World vegetable center eggplant collection: Origin, composition, seed dissemination and utilization in breeding. Front Plant Sci. 2017; 8:1484.https://doi.org/10.3389/fpls.01484

12. Statista. Production volume of brinjal in India FY 2015-2020 with an estimate for 2021. Available online at: https:// www.statista.com/statistics/1038975/india-production-ofeggplant/ statista research department. Oct 16, 2021

13. USDA ARS (United States Department of Agriculture Agricultural Research Service), National Nutrient Database for Standard Reference Release 28 (https://ndb.nal.usda.gov/ndb/). Accessed 14 March 2018.

14. Casati L, Pagani F, Braga PC, Scalzo RL, Sibilia V. Nasunin. A new player in the field of osteoblast protection against oxidative stress. J Funct Foods. 2016; 23:474-84. https://doi.org/10.1016/ j.jff.2016.03.007

15. Koul O, Wahab S. Neem: Today and in the New Millennium. New York, NY: Kluwer Academic Publishers, Springer.1st ed. 2004 edition (23 January 2011). ISBN.13:978904816269. http:// www.springeronline.com

16. Chaudhary S, Kanwar RK, Sehgal A, Cahill DM, Barrow CJ, Sehgal $\mathrm{R}$, Kanwar JR. Progress on Azadirachta indica Based Biopesticides in Replacing Synthetic Toxic Pesticides. Front Plant Sci. 2017; 8:610. https://doi.org/10.3389/fpls. 00610

17. Akhtar M. Nematicidal potential of the neem tree Azadirachta indica (A. Juss). Integr Pest Manag Rev. 2000; 5: 57-66. https:// doi.org/10.1023/A:1009609931223

18. Loknadhan S, Muthukrishnan P, Jeyaraman S. Neem products and their agricultural applications. J Biopestic. 2012; 5 (Supplementary):72-76. http://www.jbiopest.com/users/lw8/ efiles/vol_5_0_72_76f.pdf

19. Prakash J, Singh K. Control of root-knot nematode by using composted sawdust in tomato root. Afr J Biotechnol. 2014; 13:407080.https://doi.org/10.5897/AJB2014.13726

20. Mondal E, Chakraborty K. Azadirachta indica: A tree with multifaceted applications: An Overview. J Pharm Sci Res. 2016; Vol. 8 (5):299-306. https://www.jpsr.pharmainfo.in

21. Alhassanl YJ, Haruna Y, Muhammad MA, Firddausi SK. Economics of bio-based fertilizer in improving crop productivity through extension services delivery. Int J Agric Plant Sci. 2019; 1 (4):10-13. Online ISSN: 2664-7664; Print ISSN: 2664-7656. www.agriculturejournal.in

22. Siddiqui MA, Alam MM. Sawdust as soil amendments for control of nematodes infesting some vegetables. Biol Wastes. 1990; 33:123-29. https://doi.org/10.1016/0269-7483(90)90152-I

23. Yadav S, Patil J, Kumar A. Bio-nematicidal effect of Azadirachta indica, against Meloidogyne incognita in tomato. In J Chem Stud. 2018;6(3):2757-61.PISSN:23498528.EISSN:23214902.https:// www.chemijournal.com/archives/2018/vol6issue3/PartAN/6-3244-235.pdf

24. Oka Y. Mechanism of nematode suppression by organic soil amendment: A review. Appl Soil Ecol. 2010; 44:101-15. https:// doi.org/10.1016/j.apsoil.2009.11.003

25. Bernard GC, Egnin M, Bonsi C.The Impact of Plant-Parasitic Nematodes on Agriculture and Methods of Control. NematologyConcepts, Diagnosis and Control. 2017; https://doi.org/10.5772/ intechopen.68958

26. Sumbul A, Rizvi R, Salah M, Tiyagi SA, Ansari RA, Safiuddin, Mahmood I. Role of different sawdusts and bioinoculant in the management of root-knot nematode infesting chickpea. Asian J 
Crop Sci. 2015; 7: 197-206.https://doi.org/10.3923/ ajcs.2015.197.206

27. Mahaney WC, Voros J, Krishnamani R, Hancock RGV, Aufreiter S, Milner M W, Allen CCR. Physicogeochemical and mineral composition of neem tree soils and relation to organic properties. Geografiska Annaler: Series A, Phys Geogr. 2016;98:143-54.https:// doi.org/10.1111/geoa.12129

28. Carter MR, Ball B. Soil porosity. In: Carter MR (Editor) Soil sampling and methods of analysis. Canadian Society of Soil Science. Lewis Publishers, CRC Press, Boca Raton. 1993;581-88. ISBN-13: 978-0-8493-3586-0 (alk. paper). http://www.crcpress.com

29. Black CA, Evans DD, White JL, Ensmingher LE, Clarke FE, Dinauer RC. Methods of soil analysis. Part I- Physical and mineralogical properties including statistics of measurement and sampling (9 Series Agronomy). Madison, WI: American Society of Agronomy. 1965.

30. Jackson ML. Soil chemistry analysis. Prentice Hall of India, Pvt. Ltd, $1^{\text {st }}$ edition, New Delhi, India. 1973. 498

31. Ganguly AK. Base Exchange capacity of silica and silicate minerals. J Phys Chem. 1951;55:1417-28. http://dx.doi.org/10.1021/ j150492a002.

32. Richard LA. Diagnasis and improvement of saline and alkali soils. Agric. Hand book, 60, U.S. Dept, Agric. Washington DC.1954:160. https://doi.org/10.2136/sssaj1954.03615995001800030032x

33. Kjeldahl J. A new method for the determination of nitrogen in organic matter. Zeitschrift für Analytische Chemie. 1883; 22:36682. http://dx.doi.org/10.1007/BF01338151

34. Olsen SR, Cole CV, Watanabe FS, Dean LA. Estimation of available phosphorus in soils by extraction with sodium bicarbonate. Circ. United state Department of Agriculture. Circular 19, Washington DC.1954; 939:1-19.

35. Lindsay WL, Norvell WA. Development of a DTPA soil test for zinc, iron, manganese and copper. Soil Sci soc Am J. 1978; 42:42128.https://doi.org/10.2136/sssaj1978.03615995004200030009x

36. Eisenback JD, Hunt DJ. General Morphology. In: Root Knot Nematodes; Perry RN, Moens M, Starr JL, editors.; CABI: Wallingford, CT, USA, 2009; 18-54. ISBN9781845934927. https:// doi.org/10.1079/9781845934927.0018

37. Mackinney G. Absorption of light of chlorophyll solutions. J Biol Chem. 1941; 140:315-22. https://doi.org/10.1016/S0021-9258(18) 51320-X

38. Taylor AL, Sasser JN. Biology, Identification and control of rootknot nematodes (Meloidogyne spp.). Publ Dep Plant Pathol, North Carolina State Univ., and U.S. Agency Int. Dev. Raliegh, N.C. 1978 vii; 111.

39. Fisher RA. Statistical Methods for Research Workers. Oliver and Boyd, Edinburgh: Tweeddale court London: 33 Paternoster Row, E.C.1925.

40. Hassan MA, Chindo PS, Marley PS, Alegbejo. Management of rootknot nematodes (Meloidogyne spp.) on tomato (Lycopersicon lycopersicum) using organic wastes in Zaria, Nigeria. Plant Prot Sci. 2010; 46 (1):34-38. https://doi.org/10.17221/1/2009-PPS.

41. Yasin M, Jabran K, Afzal I, Iqbal S, Nawaz MA, Muhmood A, Asif M, Nadeem MA, Rahman ZU, Adnan M, Siddiqui M, Shahid MQ, Andreasen C. Industrial sawdust waste: An alternative to soilless substrate for garlic (Allium sativum L.). J Appl Res Med Aromat Plants. 2020;18:100252. https://doi.org/10.1016/ j.jmap.2020.100252

42. Seghatoleslami MJ, Mousavi G, Javedi H. Chicory (Cichorium intybus) responses to nitrogen and plant density in Birjand, Iran Int J Biosci. 2014;4(9):56-61. http://dx.doi.org/10.12692/ijb/4.9.56 $-61$

43. Misganaw A, Alemay H, Kesete N. Review on the effect of level of nitrogen on growth and yield of onion in Ethiopia. J Glob Agric
Ecol. 2021; $11 \quad(1): 1-7 . \quad$ Availablefrom: https:// archives.biciconference.co.in/index.php/jogae/article/view/6272

44. Escobar C, Barcala M, Cabrera J, Fenoll C. Overview of root-knot nematodes and giant cells. Adv Bot Res. 2015; 73, 1-32.https:// doi.org/10.1016/bs.abr.2015.01.001

45. Bozbuga R. Characterisation of cell walls at the feeding site of Meloidogyne incognita, PhD thesis, University of Leeds, Leeds. 2017.

46. Favery B, Quentin M, Jaubert Possamai S, Abad P. Gall-forming root-knot nematodes hijack key plant cellular functions to induce multinucleate and hypertrophied feeding cells. J Insect Physiol. 2016; 84:60-69.https://doi.org/10.1016/j. jinsphys.2015.07.013

47. Wendimu GY. Biology, Taxonomy and Management of the RootKnot Nematode (Meloidogyne incognita) in Sweet Potato, Adv Agric. 2021; vol. 2021:1-13 Article ID 8820211, 13 pages. https:// doi.org/10.1155/2021/8820211.

48. Hossain MA, Al-Toubi WAS, Weli AM, Al-Riyami QA, Al Sabahi JN. Identification and characterization of chemical compounds in different crude extracts from leaves of Omani neem. J Taibah Univ Sci. 2013;7:181-88. https://doi.org/10.1016/ j.jtusci.2013.05.003

49. Hayat A, Javed N, Khan SA, Gondal AS, Khan HU. Effect of organic amendments on nematode galling index and egg masses production in potato inoculated with root-knot nematode. Pak J Phytopathol. 2012;24(1):01-05. http://pakps.com/pjp/files/01-05hayat.pdf

50. Li J, Zou C, Xu J, Ji X, Niu X, Yang J, Huang X, Zhang KQ. Molecular mechanisms of nematode-nematophagous microbe interactions: basis for biological control of plant-parasitic nematodes. Annu Rev Phytopathol. 2015; 53:67-95. https://doi.org/10.1146/ annurev-phyto-080614-120336. PMID: 25938277

51. Souza RAD, Ribeiro RCF, Rocha LDS, Xavier AA, Martins IPS, Silva FDJ. Reaction of Crambe abyssinica to Meloidogyne javanica and M. incognita race 3 Rev. Caatinga Mossoro. 2019; 32 (1):276-81. http://dx.doi.org/10.1590/1983-21252019v32n128rc

52. Debia PJG, Barros BCB, Puerari HH, Ferreira JCA, Dias-Arieira CR. Induced systemic resistance in beet plants infected with Meloidogyne javanica. Chil J Agric Res. 2021; 81 (1); 70-79. http:// dx.doi.org/10.4067/S0718-58392021000100070

53. Akhtar SS, Li G, Andersen MN, Liu F. Biochar enhances yield and quality of tomato under reduced irrigation. Agricultural Water Management. 2014; 138:37-44. https://doi.org/10.1016/j.agwat.

54. Kokalis - Burelle N, Rodriguez - Kabana R, Weaver CF, King PS. Evaluation of powdered pine bark for control of Meloidogyne arenaria and Heterodera glycines on soybean. Plant Soil. 1994;162:163-68. http://www.jstor.org/stable/42939537

55. Ohri P, Pannu SK. Effect of phenolic compounds on nematodesA review. J Appl Nat Sci. 2010;2(2):344-50. https:// doi.org/10.31018/jans.v2i2.144

56. Chitwood DJ, Perry RN. Reproduction, physiology and biochemistry. In: Root-Knot Nematodes (Perry RN, Moens M, Starr JL, eds), 2009; 182-200. Wallingford, Oxfordshire:CAB International Landaon

57. Thoden TC, Korthals GW, Termorshuizen AJ. Organic amendments and their influences on plant-parasitic and free-living nematodes: a promising method for nematode management? Nematology 2011;13(2):133-53. https:// doi.org/10.1163/138855410X541834 